\title{
Impact of Corporate Governance on the Performance of Selected Indian Banks: An Empirical Based Comparative Analysis
}

\author{
Mohd Asif Intezar ${ }^{1}$, Prof. Imran Saleem ${ }^{2}$ \\ ${ }^{1}$ Research Scholar, ${ }^{2}$ Professor \\ Department of Commerce, A.M.U Aligarh, Uttar Pradesh, India
}

\begin{abstract}
Corporate Governance simply refers to the system under which the business activities have taken place on the basis of prescribed code of conduct by regulatory and monitoring authorities. Financial institutions must focus on to fulfill the expectation of stakeholders while focusing on their core target to earn profit and improve their financial strength which lead to stable economic system of particular country. The present study is based on to analyze the impact of corporate governance on the performance of eight selected Indian banks on the basis of market capitalisation. The secondary data was collected from the annual report of banks and prowess data base for ten years i.e. 2007-08 to 2017-18. Panel data regression and Pearson correlation tools are used with the help of SPSS, Eviews and Gretl. The study found that there is no significance impact of board size, board independency and capital adequacy ratio on earning per shares of selected banks but there is positive and strong significance impact of frequency of board meetings on earning per share has been found.
\end{abstract}

Key Words: Corporate Governance, EPS, BDSZ, BIND, CAR, FBM

\section{INTRODUCTION}

Indian Banking sector is required to follow the norms of corporate governance provided and guided by the new companies act 2013, revised clause 49 of SEBI regulations and also followed by the norms of international Basel committee related with the issues of capital adequacy norms for commercial banks and financial institutions. Indian banking sector has been lagging behind in term of corporate governance issues associated with disbursement of loans, scams and fraudulent activities. Involvement of high level of technological based transactions and globalization in banking sector has brought a new cross road for Indian banking sector. Governance of banking sector has always been a very crucial and challenging task due to the involvement of large numbers of stakeholders and also its consideration as one of the most important pillar of the economy.

A strong corporate governance system is required in banking sector specifically due to its exposure at international level, complex working system and accountability toward large numbers of stakeholders. Corporate governance refers to a "set of legal, cultural and institutional arrangements, and how the control is exercised, and how the risks and returns are allocated. (Blair, 1995)

"Good corporate governance is about 'intellectual honesty' and not just sticking to rules and regulations, capital flowed towards companies that practiced this types of good governance ".(Mervyn king).

Lastly corporate governance refers to the structure of corporate including relations among owners, boards and top managers determine the goal of the corporations.

\section{LITERATURE REVIEW:}

Mustafa soba revealed through his research that board independency and free float rate had negative impact on the efficiency of selected banks but major shareholders, numbers of committee $\&$ board size had positive impact on selected banks. Esra Ahmad \& Allam Hamdan(2015) has found in their study that ROA \& ROE are significantly related to corporate governance but EPS is not significantly related to corporate governance. As per the study of Najeeb 
Haider,Nabila khan \& Nadeem Iqbal concluded that there is positive relationship between board size, number of meetings and audit committee size on ROA,ROE \& EPS of selected Islamic banks. The study of Palaniappan G.(2017) concluded that there is inverse relationship between board characteristics and firms indicators while significantly negative relationship between board size and Tobin's Q,ROA and ROE followed by independence and frequency of meeting with return on equity \& return on assets. Uzma Basher (2018) revealed in her research that board size \& institutional ownership is insignificantly related with ROA, ROE \& EPS but frequency of board meetings was insignificantly related with ROA \& EPS followed by negatively significant with ROE. Dr.Ahmad Al-Baidani (2014) researched the relation between corporate governance variables and performance variables of banks where he found board meetings and banks age has positive and significant effect on ROE, Board independency and bank size have negative \& significant effects on ROA.Mohammad Rafiqul Alam \& Fahmida Akhtar (2017) revealed in their study that board size ,numbers of independent directors and number of internal audit committee members are inversely related to banks performance on the other hand there is linear relation exist between capital adequacy ratio and return on assets but non linear relation exist between capital adequacy ratio and two performance measures i.e ROE \& EPS. Adel Bino \& Shorouq Tomar (2012) found in their study that ownership structure \& board composition have strong impact on the bank performance on the other hand board size had no effect on the performance of banks.

\section{OBJECTIVE \& N RESEARCH METHODOLOGY.}

The objective of the study is twofold which include analyzing the overall impact of corporate governance on the selected banks as well as individual impact of corporate governance on selected banks. Eight Indian banks are selected on the basis of market capitalization including SBI, HDFC, ICICI, AXIS, KOTAK MAHINDRA, INDUSIND and BOB. Present study is based on secondary data and the data has been taken from bank's annual report and prowess data base, ten years data has been collected from 2007-08 to 2016-17.

The present research is based on dependent and independent variables which represent independent variables as corporate governance variables and dependent variables as performance variables of banks. Board size (BDSZ),board independency (BIND), capital adequacy ratio (CAR) and Frequency of board meetings (FBM) are taken as independent variables on the other hand earnings per share (EPS) is taken as dependent or performance variables of banks. Panel data regression and Pearson correlation are used with the help of SPSS, eviews and gretl. Panel data regression is used to analyze the cross sectional effect and individual effect of corporate governance on the performance of selected banks followed by Durbin Watson test for serial correlation and variance inflation factor for multicollinearty problems.

The panel regression model looks like:

$(\text { EPS })_{i x t}=\alpha_{i}+\beta_{1}(B D S Z)_{i \times t}+\beta_{2}(B I N D)_{i \times t}+$ $\beta_{3}(\mathrm{CAR})_{\mathrm{i} \times \mathrm{t}}+\beta_{4}(\mathrm{FBM})_{\mathrm{i} \times \mathrm{t}}+\varepsilon_{\mathrm{i} \times \mathrm{t}}$

\section{Where:}

EPS=Earnings per Share.

BDSZ=Board Size.

$\mathrm{BIND}=$ Board Independence.

CAR=Capital Adequacy Ratio.

$\mathrm{FBM}=$ Frequency of Board Meeting

$\varepsilon$ ixt $=$ error term

\section{ANALYSIS:}

Pearson correlation of coefficient is used to assess the relationship of corporate governance variables and performance variable of banks

\section{Result of Multicollinearty:}

\begin{tabular}{|c|c|c|c|c|c|}
\hline Variables & BDSZ & BIND & CAR & FBM & EPS \\
\hline BDSZ & 1.000000 & & & & \\
\hline BIND & $\mathbf{0 . 8 4 2 1 8 6}$ & 1.000000 & & & \\
\hline CAR & -0.211019 & -0.199140 & 1.000000 & & \\
\hline FBM & 0.242216 & 0.280044 & -0.527639 & 1.000000 & \\
\hline EPS & 0.399709 & 0.423453 & -0.327279 & 0.427479 & 1.000000 \\
\hline
\end{tabular}

Table-1 
Correlation between Dependent and Independent variables:

The results of correlation analysis is shown in above table 1 which clearly shows direct relationship between dependent and independent variables and also concluded that BDSZ is negatively correlated with CAR, BIND is negatively correlated with CAR.CAR is negatively correlated with FBM and EPS. Conclusively correlation analysis shows that the coefficient of correlation for all the variables but with the exception of coefficient correlation between BIND and BDSZ (0.842186) not comes under the threshold limit of 0.7 which simply means that there is a very high correlation between independent variables and found there is a problem of collineriaty so that variance inflation factor (VIF) has been calculated for model to detect the culprit variables which may created problem.

\section{Variance inflation factor:}

Variance inflation factor has been also used for collinearity problem between independent variables i.e BDSZ \& BIND to find out the culprit variables and also know about whether there will be biased result or not due to this collinearly problem.

\begin{tabular}{|c|c|c|}
\hline Model & Collinearity Statistics & \\
\hline & Tolerance & VIF \\
\hline BDSZ & .289 & 3.460 \\
\hline BIND & .284 & 3.517 \\
\hline CAR & .703 & 1.422 \\
\hline FBM & .678 & 1.474 \\
\hline
\end{tabular}

Table-2
Table 2 showing that there will be no problem due to collinearly problem between two independent variables and would not affect the result because all values are within maximum threshold value of 10 .

\section{RESULSTS OF PANEL DIAGNOSTIC TEST:}

The Panel Diagnostic test has applied and passed by three steps to decide the most appropriate technique to be applied for model among three choices of techniques i.e. pooled ols, fixed effect and random effect model. In the first step one null hypothesis has framed as pooled OLS is more appropriate than fixed effect model and the result shows in table 3 that null hypothesis is rejected due to corresponding pvalue $(0.000437555)$ is less than $5 \%$ level of significance so fixed effect model is appropriate than pooled OLS model. In the second stage Breusch Pagan test is applied with the null hypothesis that pooled ols model is more appropriate than random effect model and as per the result the null hypothesis is rejected due to corresponding $p$ value $(0.000632719)$ is less than $5 \%$ level of significant, thus random effect model is appropriate than pooled ols effect model. Finally in the last step Hausman test is applied to predict whether random effect or fixed effect model is best suitable with the help of drafting the null hypothesis that random effect model is more appropriate than fixed effect and the result show that null hypothesis is accepted as corresponding p-value $(0.507536)$ is more than $5 \%$ level of significance, therefore random effect model is more appropriate.

\begin{tabular}{|l|l|l|l|l|}
\hline \multicolumn{5}{|c}{ Summary of Panel Diagnostic Test for EPS Model } \\
\hline Test & $\begin{array}{l}\text { Choice Between } \\
\text { Models }\end{array}$ & Null Hypotheses & $\begin{array}{l}\text { p-value at 5\% level } \\
\text { of Significance }\end{array}$ & Result \\
\hline F-Test & $\begin{array}{l}\text { Pooled OLS Vs. } \\
\text { Fixed Effect }\end{array}$ & $\begin{array}{l}\text { Pooled OLS is more appropriate } \\
\text { than Fixed Effect Model. }\end{array}$ & 0.000437555 & Rejected \\
\hline $\begin{array}{l}\text { Breusch } \\
\text { Pagan Test }\end{array}$ & $\begin{array}{l}\text { Pooled OLS Vs. } \\
\text { Random Effect Model }\end{array}$ & $\begin{array}{l}\text { Pooled OLS is more appropriate } \\
\text { than Random Effect Model. }\end{array}$ & 0.000632719 & Rejected \\
\hline $\begin{array}{l}\text { Hausman } \\
\text { Test }\end{array}$ & $\begin{array}{l}\text { Fixed Effect Vs. } \\
\text { Random Effect Model }\end{array}$ & $\begin{array}{l}\text { Random Effect Model is more } \\
\text { appropriate than Fixed Effect Model. }\end{array}$ & 0.507536 & Accepted \\
\hline
\end{tabular}

\section{Table-3}

Concluded empirically and logically that random effect model is best as compare to OLS and fixed effect model for the estimation of model EPS and interpretation as well.

\section{Regression Analysis of EPS Model based on Random Effect Model: Findings and Discussions:}

As per Table 4 the effect of independent variables on dependent variables i.e. effect of board size, board independence, capital adequacy ratio and frequency of board meeting on earning per share as dependent variables with the help of pooled ols model, random effect model and fixed effect model has shown but the interpretation of result is done on the basis of most appropriate random effect model which is already been selected and discussed. 
International Journal of Trend in Scientific Research and Development (IJTSRD) ISSN: 2456-6470

\section{Pooled OLS, Fixed Effect and Random Effect Model: Model (EPS) \\ Using 80 observations, included 8 cross sections units \\ Time series length $=10$ \\ Dependent Variable: EPS \\ Robust (HAC) standard Error}

\begin{tabular}{|c|c|c|c|}
\hline Variables & Pooled OLS Model & Fixed effect model-FEM & Random effect model-REM \\
\hline \multirow{2}{*}{ Constant } & $(-16.4647)$ & $(-90.7050)$ & $(-74.6093)$ \\
& 0.8107 & 0.3025 & 0.2605 \\
\hline \multirow{2}{*}{ BDSZ } & $(2.66070)$ & $(-0.231855)$ & $(0.459027)$ \\
& 0.6148 & 0.9379 & 0.8956 \\
\hline \multirow{2}{*}{ BIND } & $(5.28031)$ & $(6.20535)$ & $(6.24420)$ \\
& 0.5455 & 0.2794 & 0.3111 \\
\hline \multirow{2}{*}{ CAR } & $(-2.30515)$ & $(3.10433)$ & $(1.69912)$ \\
& 0.3931 & 0.2173 & 0.4572 \\
\hline \multirow{2}{*}{ FBM } & $(3.45974)$ & $(5.41629)$ & $* * 13259)$ \\
& $* * * 0.0292$ & 0.2091 & 0.138820 \\
\hline R & 0.297399 & 0.516721 & 0.092890 \\
\hline Adj. R ${ }^{2}$ & 0.259927 & 0.438543 & 3.022446 \\
\hline F-statistics & 7.142747 & 6.609582 & 0.022847 \\
\hline P(value $)$ & 0.012885 & 0.000000 & 05 \\
\hline
\end{tabular}

Table-4

As per table 4 above the value of $R^{2}$ and adjusted $R^{2}$ of random effect model are favorable to explain regression EPS Model in which earning per share (EPS) represented dependent variable.

The value of $\mathrm{R}^{2}(0.516721)$ showing through fixed effect model that $51 \%$ of variation in EPS caused by selected independent variables in the model while remaining $49 \%$ variation may be due to other variables outside the model. The value of " $\mathrm{R}^{2}$ (0.297399) through pooled ols model indicating that $29 \%$ variation on EPS is caused by the selected variables while remaining $71 \%$ may be due to others variables which have not included in the model .Through random effect model the value of $\mathrm{R}^{2}$ (0.13882) indicating that $13 \%$ change in the EPS caused by selected variables and remaining $87 \%$ are due to non selected independent variables outside the model.

\section{BDSZ:}

As per table 4 the coefficient of board size (BDSZ) is positively insignificant in pooled ols model and random effect model but in the case of fixed effect model it is negatively insignificant therefore the null hypothesis is accepted that there is no significant impact of BDSZ on EPS across selected banks.

\section{BIND:}

The coefficient of board independency is positively insignificant in fixed effect model, random effect model and pooled ols model that's why accepting the null hypothesis of there is no significant impact of board independency on earning per share across selected banks.

\section{CAR:}

The coefficient of capital adequacy ratio showing positively insignificant relationship in fixed effect and random effect model but showing negatively insignificant in pooled ols, model therefore, on the basis of overall observation of coefficient the null hypothesis of no significant impact of CAR on EPS is accepted and found there is no significant impact of CAR on EPS across selected banks.

\section{FBM:}

As per table $4 \mathrm{FBM}$ is positively strong significant with pooled ols and random effect model at $1 \%$ level of significance on the other hand positively insignificant relationship has shown in fixed effect model. The null hypothesis regarding there is no impact of FBM on EPS is rejected across selected banks as per random effect model which is most appropriate in model represented by EPS as dependent variable. 
International Journal of Trend in Scientific Research and Development (IJTSRD) ISSN: 2456-6470

Summary of hypothesis testing:

\begin{tabular}{|c|l|l|c|c|c|}
\hline No. & \multicolumn{1}{|c|}{ Null Hypotheses } & \multicolumn{1}{|c|}{ Statistical Tool } & Sig. & Results & Inference \\
\hline $\mathrm{H}_{01}$ & $\begin{array}{l}\text { "There is no significant impact } \\
\text { of BDSZ on EPS across } \\
\text { selected Banks in India" }\end{array}$ & $\begin{array}{l}\text { Multiple Regression } \\
\text { Analysis (Random } \\
\text { effect Model) }\end{array}$ & 0.8956 & Accepted & Insignificant \\
\hline $\mathrm{H}_{02}$ & $\begin{array}{l}\text { "There is no significant impact } \\
\text { of BIND on EPS across } \\
\text { selected Banks in India" }\end{array}$ & $\begin{array}{l}\text { Multiple Regression } \\
\text { Analysis (Random } \\
\text { effect Model) }\end{array}$ & 0.3111 & Accepted & Insignificant \\
\hline $\mathrm{H}_{03}$ & $\begin{array}{l}\text { "There is no significant impact } \\
\text { of CAR on EPS across } \\
\text { selected Banks in India" }\end{array}$ & $\begin{array}{l}\text { Multiple Regression } \\
\text { Analysis (Random } \\
\text { effect Model) }\end{array}$ & 0.4572 & Accepted & Insignificant \\
\hline $\begin{array}{l}\text { "There is no significant impact } \\
\text { of FBM on EPS across } \\
\text { selected Banks in India" }\end{array}$ & $\begin{array}{l}\text { Multiple Regression } \\
\text { Analysis (Random } \\
\text { effect Model) }\end{array}$ & $0.0005^{* * *}$ & Rejected & Significant \\
\hline
\end{tabular}

Table-5

Impact of BDSZ on EPS: Bank Specific (EPS). It is clear from table. 6 that HDFC Bank, ICICI

\section{Heterogeneity:}

The Heterogeneity of banks has been studied and ranked on the basis of cross sectional effect by fixed effect model and random effect model but the interpretation has been done on the basis of random effect model which is most appropriate for model represented by dependent variable earning per share
Bank, KOTAK Mahindra Bank and INDUSIND Banks has no impact on their earning per share due to board size as they have negative corresponding values in table 5 but on the other hand SBI is at number one followed by Bank of Baroda at second AXIS Bank at third and YES Bank at fourth in term of impact of board size on their earning per share.

Bank specific heterogeneity for the impact of BDSZ on EPS

\begin{tabular}{|c|c|c|c|c|}
\hline \multirow{2}{*}{ Banks } & \multicolumn{2}{|c|}{ Cross sectional effect } & \multicolumn{2}{c|}{ Cross sectional effect } \\
\hline & Fixed effect & Rank & Random effect & Rank \\
\hline HDFC & -17.88694 & 6 & -15.555052 & \\
\hline SBI & 60.96754 & 1 & 47.09190 & 1 \\
\hline ICICI & -36.24485 & & -31.07587 & \\
\hline AXIS & 17.88415 & 3 & 13.07587 & 3 \\
\hline KOTAK MAHINDRA & -23.90095 & & -17.38898 & \\
\hline INDUSIND & -16.41674 & & -10.75766 & \\
\hline YES BANK & -2.985737 & & 0.403279 & 4 \\
\hline BOB & 18.58353 & 2 & 15.03056 & 2 \\
\hline
\end{tabular}

Table.6

Impact of BIND on EPS: Bank specific Heterogeneity:

Bank specific heterogeneity regarding impact of BIND on EPS has been analyzed through ranking by applying fixed effect model and random effect model. Table.7 showing that SBI bank is at numbers one in term of having highest impact of board independency on earning per share followed by AXIS Bank at second and Bank of Baroda Bank at third, on the other hand HDFC Bank, ICICI Bank, KOTAK Mahindra Bank, INDUSIND Bank and YES Bank has no significant impact of board independency on earning per share as they have negative corresponding values. 
International Journal of Trend in Scientific Research and Development (IJTSRD) ISSN: 2456-6470

Bank specific heterogeneity for the impact of BINDS on EPS

\begin{tabular}{|c|c|c|c|c|}
\hline & \multicolumn{2}{|c|}{ Cross sectional effect } & \multicolumn{2}{c|}{ Cross sectional effect } \\
\hline & Fixed effect & Rank & Random effect & Rank \\
\hline HDFC & -14.88934 & & -11.873 .5 & \\
\hline SBI & 57.55554 & 1 & 44.03651 & 1 \\
\hline ICICI & -38.65281 & & -33.84595 & \\
\hline AXIS & 21.55978 & 2 & 17.65633 & 2 \\
\hline KOTAK MAHINDRA & -21.21482 & & -15.01277 & \\
\hline INDUSIND & -17.02666 & & -12.24971 & \\
\hline Yes bank & -3.127690 & & -0.638974 & \\
\hline BOB & 15.79600 & 3 & 11.92772 & 3 \\
\hline
\end{tabular}

Table.7

Impact of CAR on EPS: Bank specific Heterogeneity:

The present study is one of its kind in term of extensive study of panel data analysis in which comparative study of different banks has also been done to check the heterogeneity through impact of CAR on EPS.Table.8 showing cross sectional effect on different selected banks on the basis of fixed effect and random effect model but the ranking of selected banks in term of impact of CAR on their EPS has concluded on the basis of random effect model as it is most appropriate method for model. It is clear from the table that there is no significant impact of capital adequacy ratio on earning per share of HDFC Bank, ICICI Bank, KOTAK MAHINDRA Bank, INDUSIND Bank and YES Bank as they are showing corresponding negative values while SBI Bank has highest impact and remain at first followed by AXIS Bank at second and Bank of Baroda Bank at third place with regard of impact of capital adequacy ratio on their earning per share.

Bank specific heterogeneity for the impact of CAR on EPS

\begin{tabular}{|c|c|c|c|c|}
\hline Banks & \multicolumn{2}{|c|}{ Cross sectional effect } & \multicolumn{2}{|c|}{ Cross sectional effect } \\
\hline 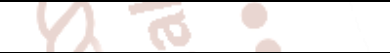 & Fixed effect & Rank & Random effect & Rank \\
\hline HDFC & -17.54143 & & -12.55161 & B \\
\hline SBI & 77.02064 & 641 & 52.91947 & 1 \\
\hline ICICI & -38.50518 & & -24.03780 & \\
\hline AXIS & 24.38316 & 3 & 16.85212 & 2 \\
\hline KOTAK MAHINDRA & -39.63218 & & -21.47791 & \\
\hline IndUSIND & -18.38075 & 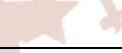 & -18.94272 & \\
\hline Yes bank & -13.67852 & & -6.885307 & \\
\hline $\mathrm{BOB}$ & 26.33426 & 2 & 14.12377 & 3 \\
\hline
\end{tabular}

\section{Impact of FBM on EPS: Bank specific} Heterogeneity:

The result of panel data analysis of eight banks has shown that out of eight banks only three banks showing the impact of frequency of board meeting on their earning per share and remaining three has insignificant impact of FBM on EPS.The present study is one of its kind in term of extensive study of panel data analysis in which comparative study of different banks has also been done to check the heterogeneity through impact of FBM on EPS. Table.9 showing cross sectional effect on different selected banks on the basis of fixed effect and random effect model but the ranking of selected banks in term of impact of FBM on their EPS has concluded on the basis of random effect model as it is most appropriate method for model. It is clear from the table that there is no significant impact of frequency of board meeting on earning per share of HDFC Bank, ICICI, KOTAK MAHINDRA Bank, INDUSIND Bank and BOB banks as they are showing negative corresponding values while SBI is at number one followed by AXIS Bank at second and YES bank at third. 
International Journal of Trend in Scientific Research and Development (IJTSRD) ISSN: 2456-6470

\section{Bank specific heterogeneity for the impact of FBM on EPS}

\begin{tabular}{|c|c|c|c|c|}
\hline & \multicolumn{2}{|c|}{ Cross sectional effect } & \multicolumn{2}{c|}{ Cross sectional effect } \\
\hline & Fixed effect & Rank & Random effect & Rank \\
\hline HDFC & -8.899556 & & -5.752468 & \\
\hline SBI & 58.42213 & 1 & 46.84744 & 1 \\
\hline ICICI & -26.42702 & & -21.00473 & \\
\hline AXIS & 23.57527 & 2 & 20.33063 & 2 \\
\hline KOTAK MAHINDRA & -23.62013 & & -18.54568 & \\
\hline INDUSIND & -20.18716 & & -16.38523 & \\
\hline YES Bank & 4.248406 & 3 & 6.952346 & 3 \\
\hline BOB & -7.111938 & & -12.44231 & \\
\hline
\end{tabular}

Table. 9

\section{CONCLUSION:}

The focus of the present study was on to assess the impact of corporate governance variables on the performance of banks with performance variables earning per share. It is found that out of four variables of corporate governance-board size, board independency, capital adequacy ratio and frequency of board meeting only frequency of board meeting has positive and strong significant impact on earnings per share (EPS) of selected banks. Whereas Board Size, Board Independency and Capital Adequacy Ratio has no significant impact on earnings per share.

On the other hand in banks specific heterogeneity for the impact of corporate governance variables on earning per share $-\mathrm{SBI}$ is at number one followed by BOB and AXIS bank at second and third place in term of impact of board size on earning per share,SBI at number one AXIS at second and BOB at third in impact of board independency on earning per share, In capital adequacy ratios impact on earnings per share SBI is at number one followed by AXIS and BOB at second and third place and finally, In impact of frequency of board meetings on earning per share SBI again at number one AXIS bank at second and YES bank at third place.

\section{REFERENCES:}

1. Basel committee on banking supervision, enhancing corporate governance in banking organisatios, 1999

2. Corporate governance and banks performance: An empirical study, IOSR journal of business and management.

3. Ahmed.Al-Baidhani (2014), "The Effects of Corporate Governance on Bank Performance: Evidence from the Arabian Peninsula". Corporate ownership \& control vol 11, issue 2 .
4. Rafiqul Alam and Fahmida Akhter(2017), “ Impact of corporate governance on the performance of commercial banks in Bangladesh". The cost \& management vol-45.

5. Jordan Journal of Business Administration, Volume 8, No. 2, 2012

6. Najeeb Haider, Nabila Khan \& Nadeem Iqbal, "Impact of corporate Governance on Firm Financial Performance in Islamic Financial Institution". International letters of social and humanistic sciences.

7. Mustafa Soba. "The impact of corporate governance practices on banks efficiency: A case of turkey". Journal of Suleiman Demivel University institute of social sciences, number 25 p.p.305-322.

8. The Impact of Corporate Governance on Firm Performance: Evidence From Bahrain Bourse Article · April 2015

9. European Journal of Management and Business Economics Vol. 26 No. 1, 2017 pp. 67-85.

10. Journal of Finance and Accounting 2018; 6(1):1117 also available at http://www.sciencepublishinggroup.com

11. "Impact of capital adequacy on the financial performance of quoted deposit money banks in Nigeria also available at https://www.researchgate.net.

12. Rafiqul Alam and Fahmida Akhter(2017) " Impact of corporate governance on the performance of commercial banks in Bangladesh". The cost \& management vol-45. 